\title{
СУЧАСНІ ФОРМИ ФІНАНСУВАННЯ ЗАКЛАДІВ ОХОРОНИ ЗДОРОВ'Я В УКРАЇНІ В КОНТЕКСТІ МЕДИЧНОЇ РЕФОРМИ
}

\author{
Квасній Любов Григорівна \\ кандидат економічних наук, доцент \\ Дрогобицький державний педагогічний університет Івана Франка (м. Дрогобич, Україна) \\ ORCID ID: 0000-0001-5248-544X \\ lg_k@ukr.net \\ Щербан Ореста Ярославівна \\ кандидат економічних наук \\ ІППт НУ «Львівська політехніка» (м. Львів, Україна) \\ ORCID ID: 0000-0001-5422-4032 \\ mppjavir@ukr.net
}

Романів Ольга Василівна кандидат економічних наук, докторант Прикарпатський інститут імеі. М. Грушевського (м. Трускавець, Україна) ORCID ID: 0000-0002-4294-1752 dunicka@bigmir.net

\author{
Попадинець Назарій Миколайович \\ кандидат економічних наук \\ ДУ «Інститут регіональних досліджень імені М. І. Долішнього НАН України» (м. Львів, Україна) \\ ORCID ID: 0000-0002-7556-6135 \\ popadynets.n@gmail.com
}

Досліджено особливості нових правил фінансування закладів охорони здоров'я в Україні в період медичної рефоорми. Визначено переваги нового принципу фінансування для медичної сфери. Виокремлено альтернативні варіанти фінансування медичних закладів, які зареєстровані у формі комунальних некомериійних підприємств, але ще не уклали договір 3 Національною службою здоров'я України. Проаналізовано можливі варіанти фінансування, що застосовуються у бюджетному законодавстві в межах медичної реформи. Запропоновано розроблення та впровадження такої системи фрінансування галузі охорони здоров'я, яка 6 врахувала як можливості громадян, так і їхні потреби. Доведено доцільність поєднання різних джерел фінансування, що дозволить значно покращити як фінансування медицини, так і якість послуг.

Ключові слова: система охорони здоров'я, медична реформа, фінансування, джерела фрінансування, медична послуга, бюджетна програма.

DOI: https://doi.org/10.32845/bsnau.2019.4.27

Постановка проблеми. Покращення медичного обслуговування населення шляхом надання якісних медичних послуг і доступність отримання медичної допомоги для більшості потребуючих громадян України - це те, на що найперше має орієнтуватись реформа системи охорони здоров'я, яка нині активно впроваджується в Україні.

У ссрері охорони здоров'я України продовжується реалізація розпочатих у 2017 р. системних змін, викладених у Концепції реформи фінансування системи охорони здоров'я, які передбачають і кардинальну зміну принципів фінансування медичної галузі. На нашу думку, саме системна робота в межах реформування галузі та вдосконалення ії фінансового механізму, враховуючи передовий досвід розвинених країн і нові управлінські технології, здатна вивести вітчизняну охорону здоров'я та медичні організації, що фінансуються в межах програми територіальних гарантій, на новий рівень ефрективності.

Аналіз останніх досліджень та публікацій. Головна мета медичної реформи полягає у вирішенні основних проблем у сфері охорони здоров'я, таких, зокрема, як низька якість та ефрективність надання медичних послуг, неефек- тивне витрачання бюджетних коштів i, як наслідок, катастрофічні витрати домогосподарств на охорону здоров'я. Суттєву увагу фінансовому забезпеченню сфрери охорони здоров'я України приділено у наукових працях М. Карп'як [1; 2], В. Шевчука [2], А. Дуба [4], С. Шульц [5] та ін. Зокрема, М. Карп'як зазначає, що медична сфера досі функціонує за залишковим принципом розподілу фінансування, основна частина якого витрачається на утримання будівель, зарплату медичного персоналу, комунальні послуги, а не спрямовується безпосередньо на надання медичної допомоги населенню та покращення якості медичних послуг. Тому медичним установам вигідно утримувати громіздку інфрраструктуру, яка $€$ підставою для визначення обсягу їх фінансування. Отже, ефективність роботи медичних закладів, якість і кількість наданих ними медичних послуг не відіграють особливого значення, а самі послуги часто дублюються закладами різного підпорядкування [5].

А. Дуб доводить неефективність механізму фінансування охорони здоров'я з використанням медичної субвенції та іï̈ причини. Автором акцентовано увагу на тому, що Закон України «Про державні фінансові гарантії надання медичних послуг та лікарських засобів» кардинально змінює механізм 
фінансування системи охорони здоров'я, усуваючи вплив адміністративної складової на розподіл коштів [4]. Проте науковцями недостатньо уваги приділено питанням нових правил фінансового забезпечення охорони здоров'я у період реформування системи охорони здоров'я, що зумовлює актуальність цієї теми дослідження.

Метою статті $€$ висвітлення особливостей нових правил фінансування закладів охорони здоров'я в Україні в період медичної ресрорми.

Виклад основного матеріалу. Необхідність і доцільність реформування системи охорони здоров'я України та впровадження нових принципів фінансування галузі не викликає сумніву, оскільки за показником витрат на охорону здоров'я на одну людину Україна займає 89-е місце у світі (серед 184 країн), а за показником тривалості життя - 108-е місце [6].

Система охорони здоров'я $€$ унікальною сферою, тому функції фінансування - це особливі види діяльності, які цілеспрямовано впливають на відносини та зв'язки людей у процесі функціонування закладів охорони здоров'я та надання медичної допомоги населенню [2]. Збільшення частки витрат на охорону здоров'я у структурі витрат на відтворення працівника, інвестиційної складової, необхідної для вдосконалення робочої сили, І. Соболєва пов'язує зі зростанням і динамікою зміни вимог до якісних характеристик людини як виробника [7].

Погоджуємось із науковими результатами досліджень М. Карп'як у тому, що фундаментом реформування медичної галузі стало ухвалення низки нормативно-правових документів, зокрема розпорядження Кабінету міністрів України від 30.11.2016 р. № 1013-р «Про затвердження Концепції реформи фінансування системи охорони здоров'я» та прийняття двох законів - «Про державні фрінансові гарантії надання медичних послуг та лікарських засобів» (від 19.10.2017р.) та «Про внесення змін до деяких законодавчих актів України щодо удосконалення законодавства з питань діяльності закладів охорони здоров'я» (від 6.04.2017р.), який передбачає автономізацію державних і комунальних закладів охорони здоров'я. У прийнятих законодавчих актах передбачається перехід вітчизняної системи охорони здоров'я до фінансування на основі моделі державного солідарного медичного страхування громадян, використовуючи для цього кошти, акумульовані у державному бюджеті [1].

Вітчизняна практика показує, що сьогодні задоволення від функціонуючої моделі фінансування немає ні у органів виконавчої влади, ні у пацієнтів. Не задоволені і страхові компанії, передусім відсутністю у них можливості брати участь в оптимізації системи охорони здоров'я, підвищенні її ефективності і збільшенні доходів від своєї участі в цій системі. Усе це підтверджує необхідність і доцільність концептуальних перетворень у вітчизняній системі охорони здоров'я. «Підвищити ефективність функціонування національної системи охорони здоров'я можна шляхом залучення додаткових джерел фінансових ресурсів і вдосконалення механізму їі фрінансового забезпечення» [8].

Дослідженням встановлено що основними джерелами фінансування медичної допомоги в Україні є такі:

1) державний і місцеві бюджети;

2) доброчинні внески юридичних і фрізичних осіб;

3) особисті (приватні) внески фрізичних та юридичних осіб за послуги, надані медичними установами;

4) безпосередня плата (гонорари) за послуги медичним працівникам;

5) фонди добровільного медичного страхування;

6) Фонд обов'язкового медичного страхування.

Для удосконалення фрінансування реформою «оптимізації» системи охорони здоров'я передбачено встановлення оптимальної структури системи охорони здоров'я шляхом ліквідації та реорганізації неефективних установ. «На папері» реформа оптимізації ставить перед собою якнайкращі цілі: підвищення якості медичної допомоги на основі підвищення ефективності діяльності медичних організацій та їх працівників. Однак, якщо проаналізувати статистичні дані, стає зрозуміло, що під прикриттям нейтрального терміна «оптимізація» в нашій країні відбувається масова ліквідація та укрупнення медичних установ, постійне скорочення медичного персоналу та постійне недофінансування закладів охорони здоров'я.

Статистичні дані показують, що державні видатки на охорону здоров'я в Україні залишаються надзвичайно низькими порівняно з іншими країнами (табл. 1).

Частка державних видатків на охорону здоров'я у ВВП країн світу, \%

\begin{tabular}{|l|c|l|c|}
\hline \multicolumn{1}{|c|}{ Країна } & \multicolumn{1}{|c|}{ Країна } & Частка у ВВП \\
\hline Голландія & Частка у ВВП & Польща & 4,7 \\
\hline Данія & 9,9 & Туреччина & 3,7 \\
\hline Франція & 9,6 & Білорусія & 3,8 \\
\hline Австрія & 9,0 & Україна & 3,4 \\
\hline Бельгія & 8,7 & Латвія & 3,1 \\
\hline Німеччина & 8,2 & Китай & 2,2 \\
\hline Японія & 8,6 & Казахстан & 2,1 \\
\hline США & 8,5 & Єгипет & 1,6 \\
\hline Швеція & 8,1 & Вірменія & 1,3 \\
\hline \multicolumn{1}{|c|}{ Велика Британія } & 7,9 & Індія & 1,1 \\
\hline Італія & 7,8 & Азербайджан & \\
\hline
\end{tabular}

Побудовано автором на основі джерела [7].

Дослідження показали, що суттєвих змін зазнає принцип фрінансування закладів охорони здоров'я первинної ланки: поліклінік, амбулаторій, центрів первинної медико-санітарної допомоги, на базі яких формується система сімейної медицини європейського зразка. Відповідно до цього принципу кожен громадянин України вільно обирає сімейного лікаря та підписує з ним прямі угоди з чітким обсягом гарантованих послуг. Відповідно, державою скеровуватимуться кошти на оплату отриманих громадянином послуг конкретному 
лікарю і конкретному медичному закладу. Отже, оплата праці медика буде нараховуватись на основі кількості укладених лікарем угод та за умов дотримання медичних протоколів лікування чи діагностики. Крім цього, враховуючи негативну ситуацію з фінансуванням у вітчизняній системі охорони здоров'я, в межах урядової програми «Доступні ліки» (відповідно до положення про Національну службу здоров'я України) впроваджуються нові правила фрінансування в системі охорони здоров'я, пов'язані з припиненням договорів про медичне обслуговування населення та договорів про реімбурсацію і запровадженням нових та єдиних правил фінансування системи охорони здоров'я, України відповідно до яких:

- пацієнти матимуть право отримати гарантований державою безоплатний пакет медичних послуг та лікарських засобів;

- НСЗУ виступає єдиним замовником та платником за програмою медичних гарантій;

- пацієнтам гарантується цільове використання державних коштів за принципом оплати якісно наданих послуг, а не на утримання медичних закладів;

- застосування прозорих методів фінансування на основі капітаційної ставки, оплати за послугу;

- збереження та посилення конкуренції та рівності надавачів послуг незалежно від форм власності;

- забезпечення прозорості на основі функціонування Електронної системи охорони здоров'я та публікації всіх звітів на сайті НСЗУ.

Крім гарантованого переліку безкоштовних медичних послуг, усі інші обстеження та необхідну медичну допомогу громадянин повинен оплатити сам. Укласти договір з НСЗУ можуть як комунальні, так і приватні медичні заклади. Щоб співпрацювати за укладеним договором з НСЗУ, медичні заклади незалежно від форми власності повинні виконати низку умов:

1. автономізуватися;

2. підключитися до Електронної системи охорони здоров'я;

3. володіти необхідним оснащенням;

4. направити заяву до НСЗУ;

5. укласти відповідні договори з медичними та фармацевтичними закладами.

Вважаємо, що співпраця з Національною службою здоров'я сприятиме відкриттю медичним закладам нових можливостей для розвитку. Трансформація системи охорони здоров'я загалом спрямована на покращення медичного обслуговування в Україні. У підсумку лікарі зможуть отримати гідну оплату праці, а пацієнти - якісні послуги, сервіс та увагу. Необхідною умовою отримання медичним закладом фінансування від Національної служби здоров'я є те, що він має бути автономізований (перетворений на комунальне некомерційне підприємство), мати чинну ліцензію, бути підключеним до системи e-Health і підписати договір з НСЗУ.

Водночас вважаємо за необхідне виокремити альтернативні варіанти фінансування медичних закладів, які зареєстровано у формі комунальних некомерційних підприємств, але ще не уклали договір з Національною службою здоров'я України. Отже, в межах бюджетного законодавства можливі такі альтернативні варіанти фрінансування охорони здоров'я:

- на основі укладення договорів про медичне обслуговування населення відповідним розпорядником бюджетних коштів;

- за бюджетною програмою - на основі фрінансування 3 відповідного бюджету 3 використанням програмноцільового методу;

- на основі фрінансової підтримки з місцевого бюджету.

У результаті цих нововведень комунальне некомерційне підприємство як одержувач бюджетних коштів зможе використовувати надані йому бюджетні кошти на підставі плану їх використання, що містить розподіл бюджетних асигнувань, затверджених у кошторисі розпорядника бюджетних коштів. Таким чином, у разі фрінансування медичної допомоги за кошти місцевого бюджету відповідний орган управління охороною здоров'я (як розпорядник бюджетних коштів) у своєму кошторисі передбачає суму витрат на закупівлю медичних послуг, яку виділила за бюджетною програмою місцева рада. Ці кошти передаються комунальному некомерційному підприємству на безповоротній основі лише за цільовим призначенням, спрямовуються на досягнення результативних показників відповідної бюджетної програми, визначених у її паспорті.

Фінансування комунального некомерційного підприємства за бюджетною програмою передбачає можливість прогнозування на два наступні бюджетні періоди (ст. 21 Бюджетного кодексу України). Тому кожного року ухвалювати відповідну бюджетну програму не потрібно. Обсяги та правила фінансування за такою програмою можуть корегуватися кожного року - під час ухвалення нового бюджету.

У разі фрінансування з місцевого бюджету шляхом надання фінансової підтримки відповідна рада під час прийняття місцевого бюджету має передбачити бюджетні кошти на фрінансову підтримку комунальному некомерційному підприємству, які можуть надаватися для виконання заходів програми соціально-економічного розвитку відповідної територіальної громади; для покриття збитків, пов'язаних із господарською діяльністю комунального некомерційного підприємства, через недостатнє фінансування; для здійснення капітальних видатків на оновлення чи закупівлю основних засобів, здійснення капітального ремонту тощо.

3 іншого боку, необхідно враховувати, що фрінансування комунального некомерційного підприємства здійснюється за скороченою класифікацією видатків бюджету, як цільове використання бюджетних коштів, і не може бути порушене [9]. Але «перекладання видатків на утримання закладів охорони здоров'я на місцеві бюджети може зумовити двоякий ефект: або відбудеться скорочення мережі (що може мати як позитивний (скорочення зайвих установ), так і негативний (ускладнення доступу до медичної допомоги певних верств населення, наприклад, осіб, які не мають змоги добиратися до лікарень чи амбулаторій в іншій громаді) наслідок), або відбуватиметься залучення кваліфікованих лікарів до медичних установ у сільській місцевості для того, щоб можна було покрити витрати на їхнє утримання (бо гроші «йтимуть» за пацієнтом)» [4].

Фінансування реорганізованого закладу охорони здоров'я за бюджетні кошти може також відбуватися за механізмом, який поєднує фінансування за бюджетною програмою та фінансову підтримку та/або укладення договору про медичне обслуговування населення. Відповідно до Закону 
України «Про державну допомогу суб'єктам господарювання» [10], державна допомога може реалізовуватись у таких фрормах:

1) надання субсидій та грантів;

2) надання дотацій;

3) надання податкових пільг;

4) відстрочення або розстрочення сплати податків, зборів чи інших обов'язкових платежів;

5) зменшення фінансових зобов'язань суб'єктів господарювання перед фондами загальнообов'язкового державного соціального страхування тощо;

6) списання боргів, включно із заборгованістю за надані державні послуги, списання штрафнних санкцій, компенсація збитків суб'єктам господарювання.

Уповноваженим органом щодо здійснення контролю за наданням державної (місцевої) допомоги є Антимонопольний комітет України, який може здійснити перевірку факту надання державної допомоги.
Висновки. Таким чином, в нинішніх умовах медичної реформи питання забезпечення закладів охорони здоров'я в Україні достатніми фінансовими ресурсами набувають особливого значення, оскільки їх обсяг (так само, як і ефективність використання) визначатиме результативність реформи. Розглядаючи кошти державного бюджету та місцевих бюджетів як джерело фінансових ресурсів, вважаємо, що бюджетне фінансування забезпечує: рівний доступ до державної медичної допомоги; можливість проведення оптимізації системи охорони здоров'я в національному масштабі; відносно просту технологію фінансування й оплати праці у цій сфері. Для подальшого розвитку медичної галузі необхідними $є$ розроблення та впровадження такої системи фінансування галузі охорони здоров'я, яка б врахувала як можливості громадян, так і їхні потреби. Для цього доцільним, на нашу думку, є поєднання різних джерел фінансування, що дозволить значно покращити як фінансування медицини, так і якість надання медичних послуг та медичної допомоги загалом.

\section{Список використаної літератури:}

1. Карп'як М. О., Попадинець Н. М. Реформування системи охорони здоров'я в Україні в умовах секторальної децентралізації. Соціально-економічний розвиток регіону: сучасні реалії та перспективи: монографія / за ред. Н. І. Пилипів. ІваноФранківськ: Видавець Віктор Дяків, 2017. 435 с.

2. Карп'як М. О., Попадинець Н. М. Оцінка функціонування сфрери охорони здоров'я в Україні в контексті євроінтеграції. Вісник Сумського національного аграрного університету. 2017. Вип. 8(77). С. 122-129.

3. Шевчук В. В. Удосконалення державного регулювання інноваційного розвитку системи охорони здоров'я в Україні. URL: https://chmnu.edu.ua/wp-content/uploads/2016/04

4. Дуб А. Р. Трансформація механізму фінансування охорони здоров'я: виклики для об'єднаних територіальних громад. Регіональна економіка. № 1. 2018. С. 76-83.

5. Розвиток соціальної сфери територіальних громад в умовах адміністративно-фінансової децентралізації / ДУ «Інститут регіональних досліджень імені М.І. Долішнього НАН України»; за ред. С. Л. Шульц. Львів, 2018. 140 с.

6. Global Competitiveness Index 2017-2018 Rankings. World Economic Forum: Website. URL: http://www3.weforum.org/docs/GCR2017-2018/05FullReport

7. Соболева И. В. Человеческий потенциал российской экономики: проблемы сохранения и развития. М.: Наука, 2007. $202 \mathrm{c}$.

8. Карпишин Н. І. Фінансове забезпечення охорони здоров'я в реалізації державних функцій на ринку медичних послуг: дис. ... канд. екон. наук: 08.04.01. Тернопіль: TДЕУ, 2006. 187 c. URL: http://dspace.tneu.edu.ua/handle/316497/895

9. Диверсифікація джерел фінансування охорони здоров'я. Національний інститут стратегічних досліджень: сайт. 18.06.2019. URL: https://niss.gov.ua/doslidzhennya/socialna-politika/diversifikaciya-dzherel-finansuvannya-okhoroni-zdorovya

10. Про державну допомогу суб'єктам господарювання: Закон України від 01.07.2014 р. № 1555-18. Законодавство України: сайт. URL: https://zakon.rada.gov.ua/laws/show/1555-18

\section{References:}

1. Karp'yak, M. O., \& Popadynets, N. M. (2018). Reformuvannya systemy okhorony zdorov"ya v Ukrayini v umovakh sektoral'noyi detsentralizatsiyi [Reforming the healthcare system in Ukraine in the context of sectoral decentralization]. In Sotsial'noekonomichnyy rozvytok rehionu: suchasni realiyi ta perspektyvy [Socio-economic development of the region: current realities and prospects]. Ivano-Frankivsk: Publisher: Viktor Dyakov. [in Ukrainian].

2. Karp'yak, M. O. \& Popadynets, N. M. (2017). Otsinka funktsionuvannya sfery okhorony zdorov'ya v Ukrayini v konteksti yevrointehratsiyi [Assessment of health sector functioning in Ukraine in the context of European integration]. Visnyk Sums'koho natsional'noho ahrarnoho universytetu - Bulletin of Sumy National Agrarian University, 8(77), $122-129$ [in Ukrainian]

3. Shevchuk, V. V. (2016). UdoskInalennya derzhavnoho rehulyuvannya innovatsiynoho rozvytku systemy okhorony zdorov"ya $\checkmark$ Ukrayini [Improvement of state regulation of innovative development of health care system in Ukraine]. Retrieved from https://chmnu.edu.ua/wp-content/uploads/2016/04 [in Ukrainian].

4. Dub, A. R. (2018). Transformatsiya mekhanizmu finansuvannya okhorony zdorov"ya: vyklyky dlya ob"yednanykh terytorial'nykh hromad [Transforming the Health Financing Facility: Challenges for United Territorial Communities]. Rehional'na ekonomika - Regional economy, 1, 76-83. [in Ukrainian].

5. Rozvytok sotsial'noyi sfery terytorial'nykh hromad v umovakh administratyvno-finansovoyi detsentralizatsiyi [Development of social sphere of territorial communities in the conditions of administrative-financial decentralization] (2018). Lviv: Dolishniy Institute of Regional Research of NAS of Ukraine. [in Ukrainian].

6. Global Competitiveness Index 2017-2018 Rankings (2018). World Economic Forum: Website. Retrieved from http://www3.weforum.org/docs/GCR2017-2018/05FullReport 
7. Soboleva, I. V. (2007). Chelovecheskiy potentsial rossiyskoy ekonomiki: problemy sokhraneniya i razvitiya [The human potential of the Russian economy: problems of conservation and development]. M.: Science. [in Russian].

8. Karpyshyn, N. I. (2006). Finansove zabezpechennya okhorony zdorov"ya v realizatsiyi derzhavnykh funktsiy na rynku medychnykh posluh [Financial support for health care in the exercise of state functions in the market of medical services]. Ph.D. in Econ. Dissertation, TSEU, Ternopil, Ukraine. Retrieved from http://dspace.tneu.edu.ua/handle/316497/895 [in Ukrainian].

9. Dyversyfikatsiya dzherel finansuvannya okhorony zdorov"ya [Diversification of sources of health financing] (2019, Jun 18). National Institute for Strategic Studies: Website. Retrieved from https://niss.gov.ua/doslidzhennya/socialna-politika/diversifikaciyadzherel-finansuvannya-okhoroni-zdorovya [in Ukrainian].

10. Pro derzhavnu dopomohu sub"yektam hospodaryuvannya [On state aid to business entities] (2014). Law of Ukraine, adopted on 2014, Jul 01, 1555-18. Legislation of Ukraine: Website. Retrieved from https://zakon.rada.gov.ua/laws/show/1555-18 [in Ukrainian]. Ukraine)

Kvasniy Lyubov Hryhorivna, PhD, Associate Professor, Drohobych State Pedagogical University Ivan Franko (Drohobych,

Shcherban Oresta Yaroslavivna, PhD, doctoral student, Precarpathian Institute named after M. Hrushevsky (Lviv, Ukraine)

Romaniv Olga Vasylivna, PhD, Associate Professor, Institute of Business and Advanced Technologies of the Lviv Polytechnic National University (Truskavets, Ukraine)

Popadynets Nazariy Mykolayovych, PhD, Dolishniy Institute of Regional Research of NAS of Ukraine (Lviv, Ukraine)

Contemporary forms of healthcare facilities funding in Ukraine in the context of the healthcare reform

The ongoing implementation of systemic changes in healthcare in Ukraine provided by the Concept of the Healthcare System Funding Reform launched in 2017 stipulates the pivotal transformation of the healthcare funding principles. In our opinion, the systemic work towards the sector's reforming and improvement of its financial mechanism based on the best practices of the developed countries and new management technology can bring domestic healthcare and medical organizations funded in the framework of the Territorial Guarantees Program to the new level of efficiency. The paper aims to outline the features of new rules of the healthcare facilities funding in Ukraine under the healthcare reform. The advantages of the new funding principle for medical science are identified. Alternative financing options for medical institutions that have been registered in the form of public utility companies but have not yet been contracted with the National Health Service of Ukraine are identified. Possible financing options applied within the framework of the budgetary legislation under the healthcare reform are analyzed. The complex of actions for the realization of funding from the local budget within the framework of a program-target method (according to the budget program) is considered. The directions of funding are determined based on the concluded agreement on public health services. The budget funding is revealed to provide: equal access to public healthcare; the possibility of optimizing the healthcare system on a national scale; relatively simple technology for funding and remuneration in this area. The main purpose of the healthcare reform is identified as addressing major health problems, such as poor quality and efficiency of healthcare services, inefficient spending of budgetary resources and, as a consequence, catastrophic healthcare costs for households. The paper suggests to develop and implement a healthcare funding system that addresses the citizens' needs. The feasibility of combining different funding sources to greatly improve both the financing of medicine and the quality of services is emphasized.

Keywords: health care system, medical reform, financing, sources of funding, medical service, budget program.

Дата надходження до редакції: 14.11.2019 р. 